\title{
ANALISIS PENERAPAN GMP PADA PRODUK KERIPIK UBI JALAR DI KOTA JAYAPURA
}

\author{
Analysis of the Implementation of GMP on Sweet Potato Chips in Jayapura City
}

\section{Novita Condro dan Gatot Budi Santoso}

Program Studi Agroteknologi, Fakultas Pertanian Kehutanan dan Kelautan, Universitas Ottow Geissler Papua, Jalan Perkutut Kotaraja Dalam, Jayapura 99225

\begin{abstract}
Crackers industry in Indonesia is mostly home industry or small and medium business enterprises, which produces crackers in a traditional way. Therefore, the quality of the product must be well maintained and meet the requirements as stated in the government regulation N0. 28. 2004 about safety, quality and nutrition of the food. Several small and medium food businesses in Jayapura has still not implement hygiene and sanitation during processing of the product. Thus, the aims of this study were to analyze and to identify the food safety of sweet potato crackers produced by small and medium business in Jayapura city whether it goes in accordance with Indonesia National Standard of Quality; to determine the level of application of Good Manufacturing Practice (GMP) of sweet potato crackers produced by home industries in Jayapura. A descriptive analysis was applied in this research by using an interview and observation to obtain information regarding processing, basic suitability of GMP, also an experimental design was applied to determine the quality of the product. Result showed that there was still limited implementation of GMP among small and medium enterprises. There were 4 home industries that produce sweet potato crackers which did not meet the criteria specified in SNI No 01-4306-1996 due to the positive contamination of the product with Escherichia coli as.
\end{abstract}

Keywords: good manufacturing practise, food safety, sweet potatoes crackers

\begin{abstract}
ABSTRAK
Industri keripik di Indonesia sebagian besar masih merupakan industri rumah tangga atau Usaha Kecil dan Menengah (UKM) yang dikerjakan secara tradisional. Mutu produk yang dihasilkan harus dijaga agar produk tersebut memenuhi standar yang telah ditetapkan, sesuai dengan Peraturan Pemerintah Nomor 28 Tahun 2004 Tentang Keamanan, Mutu dan Gizi Pangan. Beberapa usaha kecil dan menengah yang sedang berkembang di Kota Jayapura belum semua memperhatikan kebersihan lingkungan kerja saat melakukan proses produksi. Adapun tujuan penelitian ini adalah menganalisis dan mengidentifikasi produk keripik ubi jalar yang dihasilkan oleh UMKM di Kota Jayapura untuk keamanan pangan sesuai SNI; Mengetahui tingkat penerapan Good Manufacturing Practice (GMP) industri keripik ubi jalar skala Rumah Tangga di Kota jayapura. Metode penelitian dilakukan secara deskriptif melalui wawancara dan observasi untuk mendapatkan informasi mengenai pengolahan kelayakan dasar GMP, dan secara eksperimental untuk pengujian mutu produk yang dihasilkan. Berdasarkan hasil penelitian diketahui bahwa tingkat penerapan GMP masih sangat kurang. Berdasarkan hasil penelitian, diketahui bahwa dari 4 sampel IRT Keripik Ubi Jalar di kota Jayapura belum memenuhi kriteria yang ditetapkan dalam SNI No. 01-4306-1996 karena parameter cemaran mikroba (Escherchia coli) diperoleh hasil positif/mengandung E. coli.
\end{abstract}

Kata kunci: biskuit ubi jalar, keamanan pangan, pengolahan pangan yang baik 


\section{PENDAHULUAN}

Diantara bahan pangan sumber karbohidrat, ubi jalar memiliki keunggulan dan keuntungan yang sangat tinggi bagi masyarakat Indonesia yaitu ubi jalar mudah diproduksi pada berbagai lahan. Adapun kandungan kalori per $100 \mathrm{~g}$ cukup tinggi yaitu $123 \mathrm{kkal}$ dan dapat memberikan rasa kenyang dalam jumlah yang relatif sedikit serta mudah diperoleh di pasar lokal dan dapat berfungsi dengan baik sebagai substitusi dan suplementasi makanan sumber karbohidrat (Zuraida dan Supriati, 2001). Ubi jalar juga dipertimbangkan sebagai bahan untuk diolah lebih lanjut. Salah satu bentuk pengolahan ubi jalar yang cukup potensial dalam kegiatan agroindustri adalah pengolahan keripik ubi jalar.

Industri keripik di Indonesia sebagian besar masih merupakan industri rumah tangga atau Usaha Kecil dan Menengah (UKM) yang dikerjakan secara tradisional. Mutu produk yang dihasilkan dapat dijaga apabila produsen mempunyai suatu sistem yang dapat menjaga agar produk tersebut memenuhi standar yang telah ditetapkan, sesuai dengan Pasal 43 Peraturan Pemerintah Nomor 28 Tahun 2004 Tentang Keamanan, Mutu dan Gizi Pangan mengamanatkan bahwa pangan olahan yang diproduksi oleh industri rumah tangga wajib memiliki Sertifikat Produksi Pangan Industri Rumah Tangga (SPP-IRT) yang diterbitkan oleh Bupati/Walikota dan Kepala Badan Pengawasan Obat dan Makanan (BPOM) menetapkan pedoman pemberian SPP-IRT (BPOM, 2012).

Beberapa usaha kecil dan menengah yang sedang berkembang di Kota Jayapura belum semua memperhatikan kebersihan lingkungan kerja saat melakukan proses produksi. Menurut Arpah (1993), pada umumnya mutu makanan hasil industri kecil tidak konsisten dikarenakan banyak pengolah, bervariasinya bahan baku dan cara pengolahannya.

Good Manufacturing Practices (GMP) merupakan salah satu indikator bahwa sanitasi dalam operasional produksi telah dilakukan dengan baik. GMP adalah suatu pedoman yang menjelaskan cara pengolahan hasil pertanian yang baik agar menghasilkan pangan bermutu, aman, dan layak dikonsumsi (Permentan, 2010). Seperti hasil penelitian Damarasri et al. (2013), menyatakan bahwa berdasarkan hasil evaluasi desk penerapan GMP maka terdapat lima aspek pada sistem kerja UKM Tempe Tenggilis yang paling mempengaruhi keamanan dan kebersihan produk. Begitu juga menurut Choiron (2010), hasil penelitiannya menyatakan bahwa dengan penerapan GMP mampu menekan pertumbuhan kapang Aspergillus ochraceus sehingga menurunkan okratoksin pada produk kopi. Oleh karena itu, diperlukan penelitian mengenai analisis penerapan kelayakan dasar pengolahan pangan atau melalui GMP pada produk keripik ubi jalar dalam menjamin keamanan pangan.

Adapun tujuan dari penelitian ini adalah untuk mengetahui tingkat penerapan GMP pada industri keripik ubi jalar skala rumah tangga di Kota Jayapura serta menganalisis dan mengidentifikasi produk keripik ubi jalar yang dihasilkan oleh UMKM di Kota Jayapura untuk keamanan pangan sesuai SNI.

\section{METODOLOGI PENELITIAN}

Penelitian ini membahas mengenai tingkat penerapan GMP pada industri keripik ubi jalar skala rumah tangga di Kota Jayapura serta menganalisis dan mengidentifikasi produk keripik ubi jalar yang dihasilkan oleh UMKM di kota Jayapura untuk keamanan pangan sesuai SNI.

Metode yang digunakan dalam penelitian ini antara lain Metode Penelitian Deskriptif melalui observasi dan wawancara, dimana dalam pelaksanaannya dilakukan pengamatan langsung terhadap objek penelitian dan tanya jawab dengan narasumber yang dalam hal ini merupakan pengolah/pemilik UKM keripik Ubi Jalar di Kota Jayapura untuk mendapatkan informasi yang jelas menyangkut penerapan GMP; Metode Penelitian Eksperimental melalui pengujian laboratorium yang bertujuan untuk melihat hasil kelayakan produk keripik ubi jalar, dilakukan penelitian mengenai jumlah mikroba (Total Plate Count), uji E.coli dan kadar air produk untuk dibandingkan dengan Standar Nasional Indonesia. Penelitian ini dilakukan ditempat produksi keripik di Kota Jayapura dan Laboratorium Ilmu Hayati Fakultas Pertanian, Kehutanan dan Kelautan UOGP.

\section{Teknik Pengumpulan dan Analisis Data}

Data yang dikumpulkan terdiri dari data primer dan data sekunder. Data primer adalah data yang diperoleh dari hasil wawancara dan observasi langsung di tempat produksi sedangkan data sekunder adalah data yang diperoleh melalui hasil analisa laboratorium.

Analisa data dilakukan dengan menghitung rerata hasil penilaian untuk sebaran dari penerapan 
GMP di Industri Rumah Tangga Keripik, dimana penilaian dengan diberikan skor 1 untuk kondisi yang baik/dilakukan/ada/bersih dan skor 0 untuk kondisi yang buruk/tidak dilakukan/tidak/tidak bersih.

\section{Tahapan Penelitian}

1. Penelitian ini diawali dengan tahap persiapan yang meliputi penentuan sampel UKM Keripik ubi jalar dengan menggunakan metode Simple Random Sampling. Sampel merupakan industri UKM Keripik Ubi jalar yang ada di Kota Jayapura.
2. Identifikasi dan analisa penerapan GMP berdasarkan kondisi eksisting UKM Keripik Ubi jalar di Kota Jayapura melalui wawancara dan observasi yang bertujuan untuk mengetahui kondisi umum sarana dan sanitasi, penerimaan bahan baku, pengolahan, kemasan/labeling, dan pengangkutan/penyimpanan.

Pengujian mutu produk untuk menunjang analisa data mengenai kelayakan produk yang dihasilkan. Parameter yang diujikan adalah Uji Mikrobiologi: Total Plate Count (TPC) dan E. coli; Uji kimia: Kadar air produk.

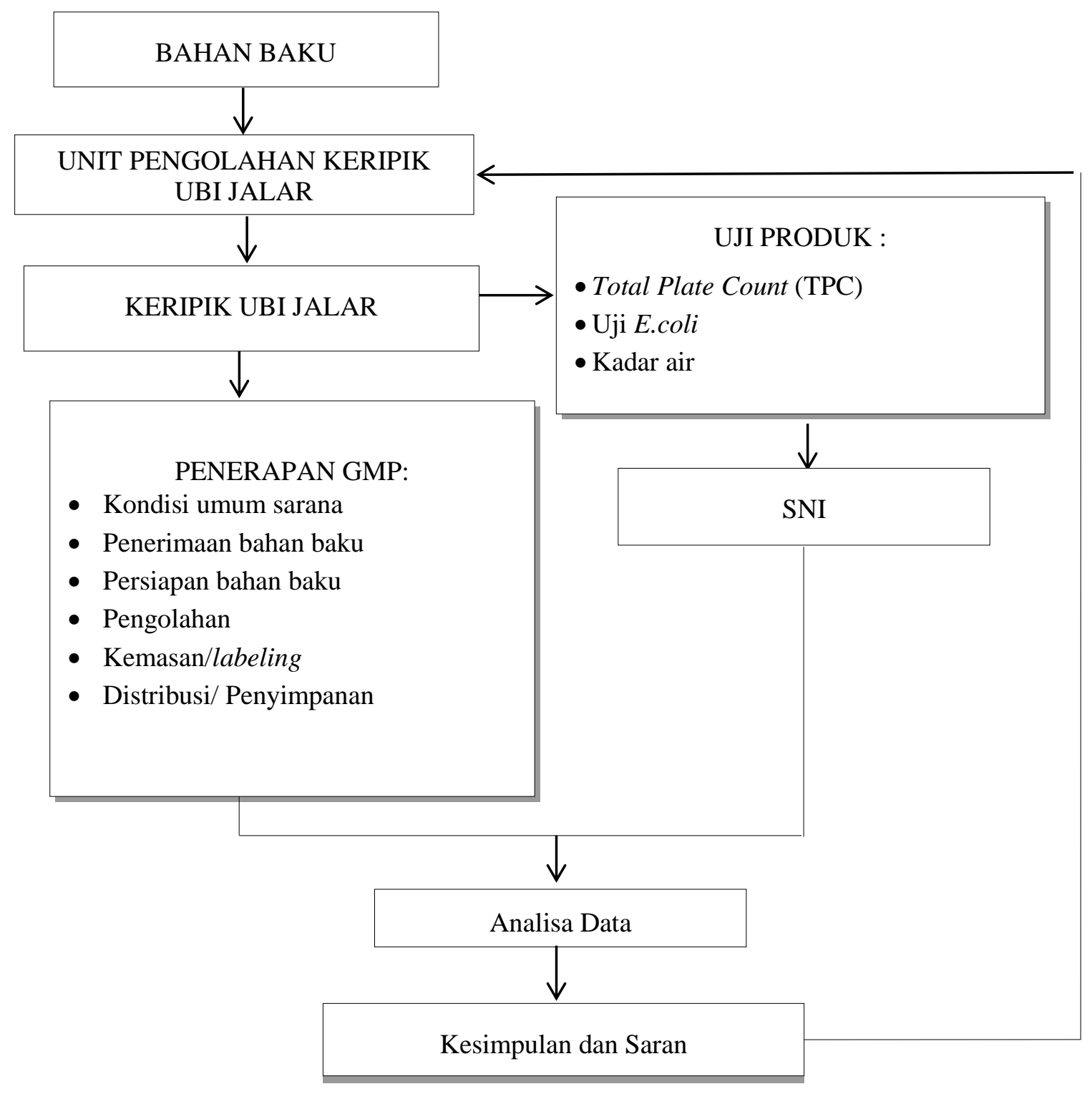

Gambar 1. Diagram alir tahapan penelitian GMP 


\section{HASIL DAN PEMBAHASAN}

\section{Analisis Penerapan GMP}

Penilaian kesesuaian penerapan GMP dilakukan terhadap enam unsur, yaitu: kondisi umum sarana yang meliputi bangunan, fasilitas sanitasi; penerimaan bahan baku meliputi tempat penerimaan, pemisahan bahan baku dan ruang penyimpanan bahan; unsur persiapan bahan baku; unsur pengolahan meliputi tahapan proses pengolahan mulai penggorengan, sanitasi alat dan ruang; unsur pengemasan meliputi jenis kemasan dan pelabelan; unsur penyimpanan/ distribusi meliputi ruang penyimpanan, sanitasi ruang produk akhir. Selanjutnya, untuk mengetahui apakah metode GMP telah diterapkan dengan baik oleh pelaku usaha keripik, maka dilakukan penjumlahan nilai dari masing-masing parameter yang diamati.

\section{Kondisi Umum Sarana}

Hasil penelitian kondisi umum sarana industri keripik skala rumah tangga tidak memenuhi persyaratan seperti kondisi dan luas bangunan, adanya ventilasi yang cukup walaupun sanitasi ruangan masih kurang diperhatikan. Hal ini dapat dilihat pada Tabel 1. dimana penilaian kondisi bangunan, luas bangunan dan ventilasi memiliki rerata 0,75 sedangkan rerata sanitasi ruangan 0,5. Menurut Syarief et al. (1999) bahwa kondisi bangunan secara umum harus memenuhi aspek pencahayaan dan ventilasi yang baik sehingga cahaya dapat tersebar ke seluruh ruangan produksi. Lingkungan tanpa sanitasi yang memadai merupakan lingkungan hidup bagi berbagai jenis bakteri pathogen. Kondisi sarana dan prasarana merupakan sumber kontaminasi yang perlu diperhatikan. Menurut BPOM (2002) bahwa peralatan pengolahan pangan yang kotor khususnya yang kontak langsung dengan pangan dapat mencemari pangan/ produk yang dihasilkan.

Tabel 1. Hasil Penilaian Kondisi Umum Sarana

\begin{tabular}{ccccc}
\hline $\begin{array}{c}\text { Nama } \\
\text { IRT }\end{array}$ & $\begin{array}{c}\text { Kondisi } \\
\text { bangunan }\end{array}$ & $\begin{array}{c}\text { Luas } \\
\text { bangunan }\end{array}$ & Ventilasi & $\begin{array}{c}\text { Sanitasi } \\
\text { ruangan }\end{array}$ \\
\hline J & 1 & 1 & 0 & 1 \\
AM & 0 & 1 & 1 & 0 \\
LJ & 1 & 1 & 1 & 1 \\
M & 1 & 0 & 1 & 0 \\
\hline Rerata & 0,75 & 0,75 & 0,75 & 0,5 \\
\hline
\end{tabular}

\section{Penerimaan Bahan Baku}

Hasil penelitian pada tahapan penerimaan bahan baku secara keseluruhan sangat baik pada keempat IRT Keripik Ubi Jalar tersebut. Hal ini dapat dilihat pada Tabel 2, dimana tempat penerimaan bahan baku bebas dari cemaran, pemisahan bahan baku dari bahan yang berbahaya memiliki rerata 1 (baik dan dilakukan). Sedangkan untuk ruang penyimpanan bahan sesuai kriteria, dari keempat sampel yang diperoleh bahwa tidak semua memiliki ruang penyimpanan khusus sesuai kriteria karena umumnya bahan baku dipersiapkan hanya untuk satu kali proses produksi dan luas bangunan produksi yang tidak luas. Menurut BPOM (2002), bahwa bahan-bahan berbahaya dapat masuk bersama-sama dengan pangan ke dalam tubuh dan menimbulkan penyakit atau keracunan. Oleh karena itu sangat penting untuk menghindari/mengurangi resiko kerusakan pangan olahan yang dihasilkan mulai dari penerimaan bahan baku.

Tabel 2. Hasil Penilaian Penerimaan Bahan Baku

\begin{tabular}{cccc}
\hline $\begin{array}{c}\text { Nama } \\
\text { IRT }\end{array}$ & $\begin{array}{c}\text { Bebas } \\
\text { dari } \\
\text { cemaran }\end{array}$ & $\begin{array}{c}\text { Pemisahan } \\
\text { bahan baku } \\
\text { dari bahan } \\
\text { lain yang } \\
\text { berbahaya }\end{array}$ & $\begin{array}{c}\text { Ruang } \\
\text { penyimpanan } \\
\text { bahan sesuai } \\
\text { kriteria }\end{array}$ \\
\hline J & 1 & 1 & 1 \\
AM & 1 & 1 & 0 \\
LJ & 1 & 1 & 0 \\
M & 1 & 1 & 1 \\
\hline Rerata & 1 & 1 & 0,5 \\
\hline
\end{tabular}

\section{Persiapan Bahan Baku}

Persiapan bahan baku mempunyai peranan penting terhadap mutu produk yang dihasilkan karena pada tahapan ini dipilah bahan dengan kondisi baik dan masih layak digunakan atau tidak (sortasi), penggunaan air yang harus diperhatikan sumber air itu berasal serta peralatan yang akan digunakan selama proses pengolahan berlangsung. Hasil pengamatan pada IRT keripik ubi jalar ini diperoleh rerata 0,5 untuk sortasi karena ada beberapa IRT yang tidak melakukan penyortiran ubi jalar/keladi yang diterima, melainkan ubi/keladi yang telah diterima dari pemasok langsung diolah tanpa disortir terlebih dahulu. Selain itu, persiapan bahan baku lain, seperti campuran bumbu atau bahan tambahan lain yang digunakan dalam proses pembuatan keripik ini, tidak menggunakan bahan yang berbahaya. 
Untuk sumber air pencucian bahan baku memiliki skor 1 atau baik karena air yang digunakan adalah berasal dari PDAM sedangkan untuk kebersihan alat potong dapat dikatakan secara umum kurang layak karena alat potong yang digunakan hanya dibersihkan dengan kain tanpa dicuci terlebih dahulu, hal ini dapat dilihat dari hasil penilaian rerata 0,25 .

Tabel 3. Hasil Penilaian Persiapan Bahan Baku

\begin{tabular}{cccc}
\hline $\begin{array}{c}\text { Nama } \\
\text { IRT }\end{array}$ & Sortasi & $\begin{array}{c}\text { Sumber } \\
\text { air untuk } \\
\text { pencucian }\end{array}$ & $\begin{array}{c}\text { Kebersihan } \\
\text { alat pemotong }\end{array}$ \\
\hline J & 0 & 1 & 1 \\
AM & 1 & 1 & 0 \\
LJ & 1 & 1 & 0 \\
M & 0 & 1 & 0 \\
\hline RERATA & 0,5 & 1 & 0,25 \\
\hline
\end{tabular}

\section{Proses Pengolahan}

Proses pengolahan dalam pembuatan keripik ubi jalar/keladi yang utama adalah pada tahapan penggorengan. Pada tahapan ini akan ikut menentukan kualitas keripik yang dihasilkan. Penilaian pengolahan dilihat pada aspek penggunaan minyak goreng, sanitasi alat dan ruangan produksi serta kebersihan dan kesehatan pekerja seperti dapat dilihat pada Tabel 4.

Penggorengan dengan menggunakan minyak goreng perlu mendapat perhatian, karena minyak goreng yang digunakan secara berulang dapat mempengaruhi mutu produk pangan. Pada hasil pengamatan di lapangan, diketahui bahwa penggorengan dilakukan dengan minyak goreng yang digunakan berulang-ulang kali dengan rerata nilai 0,5. Dari 4 sampel, diperoleh bahwa 2 di antaranya menggunakan minyak goreng hingga warna dari minyak goreng tersebut menjadi kehitaman. Menurut Ketaren (2008), minyak yang telah rusak tidak hanya mengakibatkan kerusakan nilai gizi tetapi juga merusak tekstur dan citarasa dari bahan pangan yang digoreng.

Sanitasi alat dan ruang produksi perlu dijaga karena berhubungan langsung dengan bahan yang diolah. Untuk sanitasi alat dan ruang produksi masih kurang dengan nilai rerata 0,75. Menurut Winarno dan Suroso (2004), sanitasi peralatan dilakukan dengan cara menjaga agar permukaan perlatan dan perlengkapan yang berhubungan langsung dengan bahan dan produk akhir harus halus, bebas dari lubang dan celah, sambungan rata dan tidak menyerap air, tidak berkarat dan tidak beracun.

Begitu pula dengan kebersihan dan kesehatan pekerja masih kurang hal ini tampak dari rerata hasil penilaian sebesar 0,5. Ada empat hal yang harus diperhatikan yaitu pendidikan dan pelatihan secara teratur bagi seluruh karyawan, pemeriksaan kesehatan karyawan, kebersihan lingkungan kerja dan pengawasan yang ketat mengenai praktek sanitasi yang benar (Winarno dan Suroso, 2004).

Tabel 4. Hasil Penilaian Pengolahan

\begin{tabular}{cccc}
\hline $\begin{array}{c}\text { Nama } \\
\text { IRT }\end{array}$ & $\begin{array}{c}\text { Penggunaan } \\
\text { minyak } \\
\text { goreng }\end{array}$ & $\begin{array}{c}\text { Sanitasi } \\
\text { alat dan } \\
\text { ruangan }\end{array}$ & $\begin{array}{c}\text { Kebersihan } \\
\text { dan } \\
\text { kesehatan } \\
\text { pekerja }\end{array}$ \\
\hline J & 0 & 1 & 1 \\
AM & 1 & 0 & 0 \\
LJ & 1 & 1 & 1 \\
M & 0 & 1 & 0 \\
\hline Rerata & 0,5 & 0,75 & 0,5 \\
\hline
\end{tabular}

\section{Pengemasan}

Penggunaan pengemasan yang tepat dapat menjamin mutu dan keamanan produk. Pengemasan juga mempunyai pengaruh terhadap nilai jual produk yang ditawarkan. Berdasarkan Permentan No. 20 Tahun 2010 tentang Sistem Jaminan Mutu Hasil Pertanian bahwa setiap pangan yang diedarkan untuk menghindari terjadinya kontaminasi dilakukan pengemasan dan harus terbuat dari bahan yang dapat melindungi dan tidak mengkontaminasi produk.

Tabel 5. Hasil Penilaian Pengemasan

\begin{tabular}{ccc}
\hline $\begin{array}{c}\text { Nama } \\
\text { IRT }\end{array}$ & Food Grade & Pelabelan \\
\hline J & 1 & 1 \\
AM & 1 & 1 \\
LJ & 1 & 1 \\
M & 1 & 1 \\
\hline Rerata & 1 & 1 \\
\hline
\end{tabular}

Dari hasil penelitian di lapangan, diketahui bahwa dari sampel beberapa IRT Keripik ubi jalar/keladi di Jayapura telah menggunakan bahan pengemas yang plastik PP yang diberi label mengenai informasi tempat produksi dan nomor SPP IRT bagi yang telah memiliki. Hal ini dapat dilihat pada Tabel 5 . 


\section{Penyimpanan dan Pengangkutan}

Dari hasil penilaian proses penyimpanan dan pengangkutan diperoleh nilai $<1$. Hal ini berarti dalam proses penyimpanan dan pengangkutan masih sangat kurang diperhatikan. Pada tahapan akhir yakni penyimpanan dan pengakutan diketahui bahwa pada beberapa IRT yang ada ini tidak memiliki ruangan khusus penyimpanan produk yang dihasilkan. Hal ini dikarenakan proses produksi yang berjalan pada hari tersebut langsung didistribusikan atau dijual. Hasil penilaian terhadap penyimpanan dan pengakutan dapat dilihat pada Tabel 6.

Tabel 6. Hasil Penilaian Penyimpanan dan Pengangkutan

\begin{tabular}{|c|c|c|c|c|}
\hline $\begin{array}{l}\text { Nama } \\
\text { IRT }\end{array}$ & $\begin{array}{c}\text { Kebers } \\
\text { ihan } \\
\text { ruang } \\
\text { penyim } \\
\text { panan }\end{array}$ & $\begin{array}{c}\text { Sirkulasi } \\
\text { udara }\end{array}$ & $\begin{array}{c}\text { Pember } \\
\text { sihan } \\
\text { berkala }\end{array}$ & $\begin{array}{c}\text { Kebersih } \\
\text { an wadah } \\
\text { untuk } \\
\text { distribusi }\end{array}$ \\
\hline $\mathrm{J}$ & 1 & 0 & 0 & 1 \\
\hline AM & 0 & 0 & 0 & 1 \\
\hline LJ & 1 & 1 & 1 & 1 \\
\hline M & 0 & 1 & 0 & 0 \\
\hline $\begin{array}{c}\text { Rera } \\
\text { ta }\end{array}$ & 0,5 & 0,5 & 0,25 & 0,75 \\
\hline
\end{tabular}

\section{Pengujian Mutu Produk}

Pengujian mutu produk pada sampel dari beberapa IRT ini meliputi uji kimiawi dan uji mikrobiologi. Uji kimiawi (kadar air) dilakukan dengan metode thermogravimetri, sedangkan untuk uji mikrobiologi dilakukan uji Total Plate Count (TPC) dan uji Escherchia coli.

Tabel 7. Data Uji Produk

\begin{tabular}{cccl}
\hline Sampel & $\begin{array}{c}\text { Kadar } \\
\text { Air }\end{array}$ & Nilai TPC & E. coli \\
\hline J & $1.57 \%$ & $2.0 \times 10^{3}$ & Positif \\
AM & $1.87 \%$ & $1.0 \times 10^{2}$ & Positif \\
LJ & $1.93 \%$ & $6.0 \times 10^{2}$ & Positif \\
M & $1.97 \%$ & $1.4 \times 10^{3}$ & Positif \\
\hline
\end{tabular}

Pada Tabel 7, menunjukkan bahwa keripik yang dihasilkan berdasarkan uji kimiawi meliputi kadar air sesuai dengan yang disyaratkan oleh SNI Keripik Ubi Jalar yakni $<5 \%$. Pada produk kering seperti keripik atau crakers, kadar air merupakan hal yang sangat penting karena berhubungan dengan kerenyahan. Semakin rendah kadar air keripik maka makin renyah (Sulistyowati, 2004).

Analisis mikrobiologi Total Plate Count merupakan metode yang digunakan untuk menghitung total mikroorganisme yang ada pada sampel. Pada pengujian ini menggunakan media padat dengan hasil akhir berupa koloni yang diamati secara visual berupa angka dalam koloni (cfu) per $\mathrm{ml} / \mathrm{g}$ atau koloni/100 $\mathrm{ml}$. Dari hasil analisis diperoleh nilai Total Plate Count diperoleh $1,0 \times 10^{2}$ sampai $2,0 \times 10^{3}$. Nilai teresebut bila dibandingkan dengan batas maksimum yang ditentukan oleh SNI maka jumlah tersebut masih berada dibawah batas maksimum $10^{4}$.

Pada penelitian ini, dilakukan juga analisis mikrobiologi yakni uji Escherchia coli yang merupakan bakteri yang umumnya dijadikan indikator cemaran mikroba. Menurut BPOM (2009) cemaran mikroba adalah cemaran dalam makanan yang berasal dari mikroba yang dapat merugikan dan membahayakan kesehatan manusia. Regulasi yang ditetapkan oleh BPOM RI bahwa $E$. coli tidak boleh ada pada makanan. Hal ini sesuai juga dengan SNI Keripik Ubi Jalar yang mensyaratkan bahwa $E$. coli negatif (tidak ada) pada keripik yang dihasilkan. Uji mikroba yang dilakukan pada sampel diperoleh hasil positif E. coli. Adanya E.coli pada sampel diduga karena dalam proses produksi mulai dari penerimaan bahan baku hingga produk akhir serta kondisi umum bangunan dan sarana yang digunakan tidak diperhatikan aspek sanitasi dan higienitasnya. Hal ini dapat terjadi karena kurangnya pemahaman mengenai cara pengolahan pangan yang benar serta tidak adanya standar sanitasi operesional prosedur yang diterapkan baik sebagai pemilik usaha maupun pekerjanya.

\section{KESIMPULAN}

Penilaian kesesuaian penerapan GMP dilakukan terhadap 6 unsur, yaitu: kondisi umum sarana; penerimaan bahan baku; unsur persiapan bahan baku; unsur pengolahan; unsur pengemasan dan pelabelan; unsur penyimpanan/distribusi. Berdasarkan hasil penelitian, dari keempat sampel IRT Keripik ubi Jalar di Kota Jayapura diketahui bahwa tingkat penerapan Good Manufacturing Practices (GMP) masih sangat kurang. Selain itu, diketahui pula bahwa dari empat sampel IRT Keripik Ubi Jalar di Kota Jayapura belum memenuhi kriteria yang ditetapkan dalam SNI No. 
01-4306-1996 karena parameter cemaran mikroba (E. coli) diperoleh hasil positif/mengandung E. coli.

\section{DAFTAR PUSTAKA}

Arpah, M. 1993. Pengawasan Mutu Pangan. Penerbit Warsito. Bandung.

Badan Pengawas Obat dan Makanan. 2002. Panduan Pengolahan Pangan Yang Baik Bagi IRT. Jakarta.

Badan Pengawas Obat dan Makanan Republik Indonesia. 2009. Peraturan Kepala Badan Pengawas Obat dan Makanan Republik Indonesia, Tentang Penetapan Batasan Maksimum Cemaran Mikroba dan Kimia dalam Makanan No. HK.00.06.1.52.4011.

Badan Standarisasi Nasional Indonesia. 1996. Standarisasi Nasional Indonesia Keripik Ubi Jalar No. 01-4306-1996.

Choirun, M. 2010. Penerapan GMP pada penanganan pasca panen kopi rakyat untuk menurunkan okratoksin produk kopi (Studi Kasus di Sidomulyo, Jember). Jurnal AGROINTEK 4: 114-120.

Damarasri, D.R., S.G. Partiwi, dan J. Gunawan. 2013. Penerapan Good Manufacturing
Practice dan Work Improvement in Small Enterprise Pada Usaha Kecil dan Menengah Untuk Pemenuhan Standar Kesehatan (Studi Kasus: UKM Tempe Tenggilis Mejoyo Surabaya). Jurusan Teknik Industri ITS.

Ketaren, S. 2008. Pengantar Teknologi Minyak dan Lemak Pangan. UI Press. Jakarta.

Peraturan Pemerintah RI No. 28 Tahun 2004 tentang Keamanan Mutu dan Gizi Pangan.

Peraturan Menteri Pertanian. 2010. Sistem Jaminan Mutu Pangan Hasil Pertanian. Nomor: 20/Permentan/OT.140/2/2010 Tentang.

Sulistyowati, A. 2004. Membuat Keripik Buah dan Sayur. Puspa Swara. Jakarta.

Syarief, R., Hermanto, dan J. Hariyadi. 1999. Wacana Tempe Indonesia. Universitas Katolik Widya Mandala Press. Surabaya.

Winarno, F.G, dan Surono. 2004. GMP, Cara Pengolahan Pangan yang Baik. Mbrio Press. Bogor.

Zuraida, N. dan Y. Supriati. 2001. Usahatani ubi jalar sebagai bahan pangan alternatif dan diversifikasi sumber karbohidrat. Bulletin Agrobio 4: 13-23. 